\title{
Application of Kano questionnaire to assess the level of teaching staff's quality from the student's point of view
}

\author{
Anna SZELIGA-DUCHNOWSKA \\ WSB University in Wroclaw, Poland \\ Mirosława SZEWCZYK \\ Opole University of Technology, Poland
}

\begin{abstract}
:
Aim: The aim of the paper is to present the possibility of using Kano method by a student to assess teaching staff's quality level.

Design / Research methods: The research method encompassed the analysis of the subject-specific literature and the authors' own research employing Kano questionnaire. The survey was carried out in November 2016. The lecturer characteristics from the student's point of view have been diagnosed, including their prioritization, which allowed for determining the teaching staff's quality level and student satisfaction with lecturers. The qualities requiring further development were indicated.
\end{abstract}

Conclusions / findings: The study shows that university authorities should primarily provide lecturers with good theoretical knowledge and capable of defining clearly the student's obligations.

Originality / value of the article: The authors recommend that higher education institutions use Kano questionnaire instead of traditional surveys for evaluation of teaching staff by students.

Implications of the research: Kano questionnaire can be applied in a variety of branches and can relate to various products and services, with the aim to point to their qualitative characteristics which should be developed in particular and those which are immaterial to the customer.

Limitations of the research (if applicable): The selection of elements for the sample was of a nonrandom character. Because of the subject matter dealt with by the authors in this paper, as well as due to limitations of space, only some of the results obtained were presented - the evaluation of lecturers. The survey also included other categories which - in the students' opinions - are decisive regarding the quality of educational service, such as: organization of study courses, seminar timetable, facilitations, and infrastructure.

Key words: Kano method, quality, student, satisfaction, lecturer JEL: L8, L83, L15

Correspondence address: Anna Szeliga-Duchnowska, WSB University in Wrocław, ul. Fabryczna 29-31, 53-609 Wrocław, Poland. E-mail: anna.szeliga-duchnowska@wsb.wroclaw.p .

Received: 26-04-2017, Revised: 11-09-2017, Accepted: 15-10-2017

doi: http://dx.doi.org/10.29015/cerem.464. 


\section{Anna SZELIGA-DUCHNOWSKA, Mirosława SZEWCZYK}

\section{Introduction}

As the major determinants in terms of the development of the higher education system in the long term one could cite the changes in birth rates and in the age structure of the population. The decline in the number of candidates for tertiary education observed over the last years has necessitated alterations in the way postsecondary education institutions function. Universities compete with one another to win the client - student. When faced with a strong competition, not only wining clients but retaining them becomes a key issue. This in turn puts a demand on higher education institutions to evaluate the level of student satisfaction with a view to obtain information on the changing needs, preferences and expectations.

It is broadly agreed that there is a positive relationship between well-conducted classes and the client's - student's- satisfaction. A good and experienced teacher is highly appreciated by students (Xiao, Wilkins 2015: 98-110; Drule et al. 2014: 827840). Studies conducted on a group of students attending economic universities in Upper Silesia showed that didactic and subject-specific skills were one of the most important attributes of universities ensuring the quality of education (Ratajczak 2012: 182). Moreover, a study carried out on a group of students among those studying at the University of Economics of Poznan which focused on the weights of specific characteristics of the University found that a good teaching staff was of extreme importance to students (Fazlagić 2012: 77-85).

The aim of the paper is to present the possibilities of the application of Kano method for the evaluation of the teaching staff quality. To this end, the analysis of literature and Kano questionnaire were employed, with the usefulness of Kano questionnaire in this type of research being verified in numerous publications (Grudowski, Dembowski 2012: 77-87; Malinowska 2010: 467-477; Arefi et al. 2012:347-353; Sia, Muthusamy 2012: 230-235; Malinowska et al. 2014: 235-247; Bauk et al. 2014; Dominici, Palumbo 2013: 87-96; Mayers, Jones 2012: 5-18; Taifa, Desai 2016: 569-582) 


\section{The essence of Kano method in the light of literature}

The prominent Japanese lecturer and expert in management systems, professor at Tokyo University of Science - Noriaki Kano devised the "theory of attractive quality" and the Kano model described for the first time in 1979 (Detyna 2011: 6061) (see Fig.1).

\section{Figure 1. Kano Model}

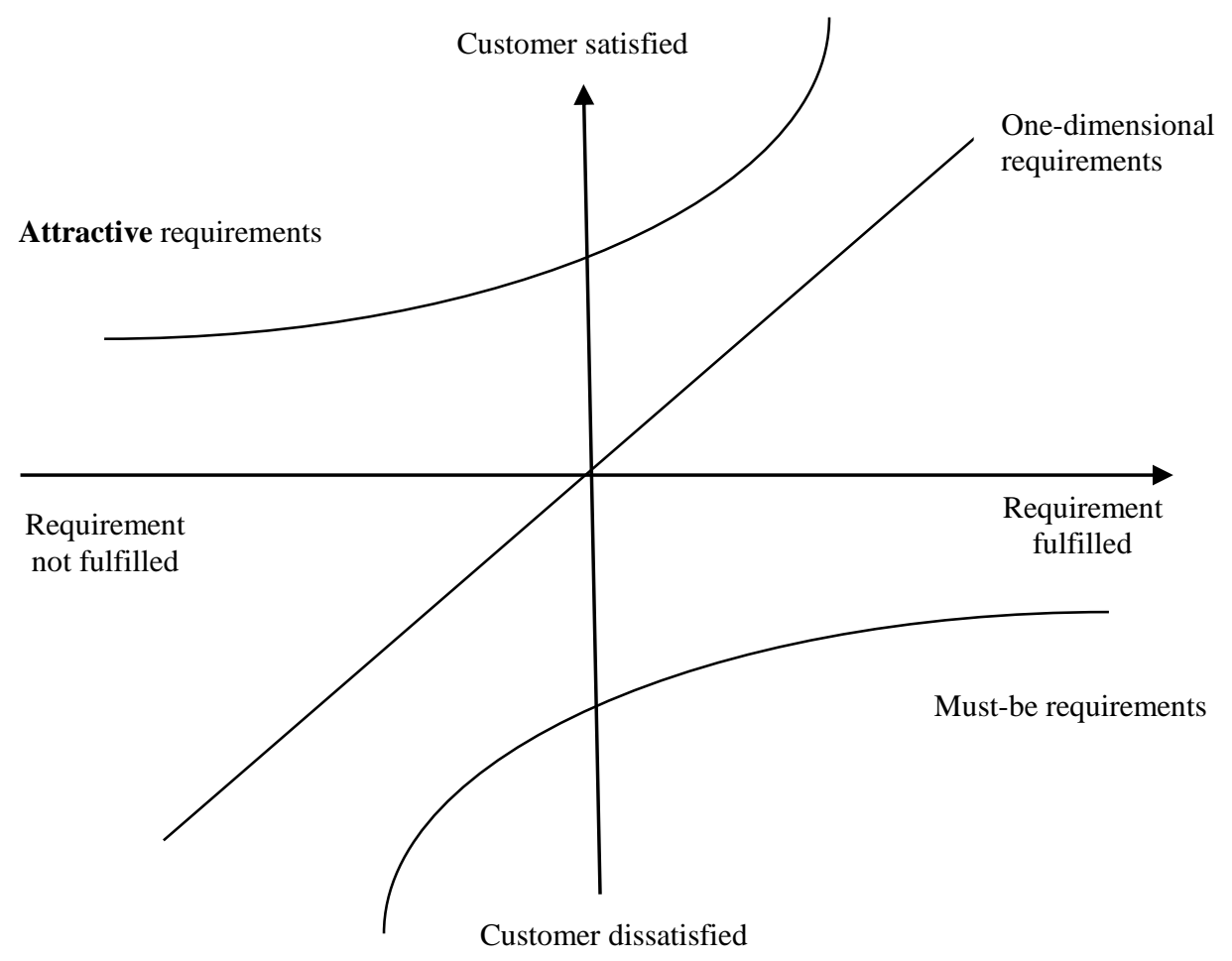

Source: own presentation based on Hamrol 2007: 24-25.

Kano proposed to see the quality of a product (make, service) at the three levels of requirements which define the following (Kano et al. 1984):

- basic qualities - required by clients, marked as " $M$ "(must be), 


\section{Anna SZELIGA-DUCHNOWSKA, Mirosława SZEWCZYK}

- expected qualities - so called performance, marked as "O" (onedimensional),

- attractive qualities - so called excitement, that is those qualities which the client does not expect, marked as "A" (Attractive).

Products or services must be characterized by certain basic qualities - without them the product is not what it is supposed to be. According to Kano model, the basic qualities in themselves exert a limited influence on the client's satisfaction. For instance, a service in the form of an academic lecture without basic qualities will not render the client/student satisfied.

For the client to feel satisfied, the product/service must additionally contain qualities which the client expects (e.g. a car in a certain class must have some specific parameters; a university teacher must run classes at a certain level). In the Kano model, it is assumed that the client's satisfaction level is proportional to the number of the expected qualities (distinguished in the product and noticed by the client). The highest quality is offered by the products which have the features which other products on the market (similar) do not have, in other words, this is a group of attractive qualities, causing excitement (the client does not expect them to come up). The excitement qualities are those characteristics which distinguish our products from those produced by the competition and (a necessary requirement) have influence on clients' increased satisfaction. Their task is to exceed the client's expectations. However, one needs to improve this group of qualities continuously as over time they are no longer up-to-date - they are by then commonly used by the competition, becoming a basic or desirable quality, e.g. seminars on-line may be attractive for some time for listeners/students but as time goes by the excitement derived from the opportunity to study in this way is likely to diminish.

The Kano model shows that meeting merely the basic needs can only make clients accept a product (the curve describing the client's satisfaction level does not cross the neutral zone). In order for the client to be delighted about a particular product, it has to fulfill certain criteria associated with performance and attractiveness.

Apart from the categories such as "basic", "expected" and "attractive", the Kano questionnaire should encompass additional categories, i.e. (et al. 1984): 
- "questionable", marked as "Q" - occurs when the client on the one hand shows satisfaction with one particular quality/characteristics, yet, on the other hand, he/she is not sure of this and shows dissatisfaction

- "indifferent", marked as "I" - when the client finds the quality completely indifferent

- "reverse", marked as "R" - occurs when the client likes the fact that this quality is present or he/she does not like the fact that it is present.

With the method thus outlined, Kano devised a questionnaire on its basis with a view to identify individual features of a particular product and to assign them to one of the groups indicated above. In the questionnaire, the respondent is asked to answer the questions in two dimensions: the positive one - when a given quality is present and fulfills its task correctly and the negative dimension - when a specific feature does not exist or if it does, it is not in a satisfactory way. Kano questionnaire tends to be created based on the questions which are developed according to the model indicated in Table 1.

Table 1. The structure of questions and answers in Kano questionnaire

\begin{tabular}{|l|l|l|}
\cline { 2 - 3 } \multicolumn{1}{c|}{ Questions } & \multicolumn{1}{c|}{ Positive dimension } & \multicolumn{1}{c|}{ Negative dimension } \\
\hline \multirow{5}{*}{ Answers } & $\begin{array}{l}\text { How do you feel when a } \\
\text { specific quality is present? }\end{array}$ & $\begin{array}{l}\text { How do you feel when a specific } \\
\text { quality is not present (or it is } \\
\text { defective)? }\end{array}$ \\
\hline & $\begin{array}{l}\text { A. I like it } \\
\text { B. It must be that way } \\
\text { C. I am neutral } \\
\text { D. I can live with it that way } \\
\text { E. I dislike it }\end{array}$ & $\begin{array}{l}\text { A. I like } \\
\text { B. It must be that way }\end{array}$ \\
& $\begin{array}{l}\text { C. I am neutral } \\
\text { D. I can live with that }\end{array}$ \\
\hline
\end{tabular}

Source: Wolniak, Skotnicka 2008: 143-144.

Placing the questions in the structure indicated above has the effect that every quality of a product/service is attributed with two answers, which in turn gives as many as 25 correlation variants, since there are five possible answers for each question. The results collected through the application of the Kano questionnaire are 
presented in the table specifying the quality type in certain determinants (Wolniak, Skotnicka 2008: 143-144) (see Table 2).

\section{Table 2. The quality type in Kano method}

\begin{tabular}{|l|l|l|l|l|l|l|}
\hline Quality & \multicolumn{7}{|c|}{ Negative } \\
\hline \multirow{3}{*}{} & Satisfaction & Like & $\begin{array}{l}\text { Must- } \\
\text { be }\end{array}$ & Neutral & $\begin{array}{l}\text { Live } \\
\text { with }\end{array}$ & Dislike \\
\cline { 2 - 8 } & Like & Q & A & A & A & O \\
\cline { 2 - 8 } & Must be & R & I & I & I & M \\
\cline { 2 - 8 } & Neutral & R & I & I & I & M \\
\cline { 2 - 8 } & Live with & R & I & I & I & M \\
\cline { 2 - 7 } & Dislike & R & R & R & R & Q \\
\hline
\end{tabular}

Source: Wolniak, Skotnicka 2008: 144.

One category (A, M, O, R, Q, I) is defined based on the highest number of indications within one quality. In order to avoid anomalies/distortions which may arise on account of questions posed in the wrong way and their negative reception by respondent/client, the following rule should be applied:

If $(\mathrm{A}+\mathrm{M}+\mathrm{O})>(\mathrm{R}+\mathrm{Q}+\mathrm{I})$, then we denote the category as $\mathrm{A}$ or $\mathrm{M}$ or $\mathrm{O}$, with the highest value;

If $(\mathrm{A}+\mathrm{M}+\mathrm{O})<(\mathrm{R}+\mathrm{Q}+\mathrm{I})$, then we denote the category as $\mathrm{R}$ or $\mathrm{Q}$ or I with the highest value.

The next stage consists in sorting out the qualities according to the following rule: $\mathrm{M}>\mathrm{O}>\mathrm{A}>\mathrm{I}$, if the quality of a particular category is not present, one should move on to the next one, omitting the qualities from the group $\mathrm{Q}$ and $\mathrm{R}$. This kind of sorting out shows the most important qualities of a product, that is, the qualities required by the client and in need of further development (Sauerwein et al. 1996: 313-327).

By conducting the analysis of the results obtained, one can evaluate the influence of individual qualities of a product on the extent of total satisfaction (CSI). To this end, one investigates the extent of satisfaction (SI) and of dissatisfaction. To obtain the overall satisfaction evaluation (CSI) one has to sum up the extent of satisfaction (SI) and of dissatisfaction (DI) (Berger et al. 1993: 3-36; Bilgili et al. 2011: 829846). 
Extent of satisfaction $\mathrm{SI}=\frac{\mathrm{A}+\mathrm{O}}{\mathrm{A}+\mathrm{O}+\mathrm{I}+\mathrm{M}}, \quad \mathrm{SI} \in[0,1]$

Extent of dissatisfaction $\mathrm{DI}=\frac{(-1)(\mathrm{O}+\mathrm{M})}{\mathrm{A}+\mathrm{O}+\mathrm{I}+\mathrm{M}}, \mathrm{DI} \in[-1,0]$

Overall satisfaction $\quad \mathrm{CSI}=\mathrm{SI}+\mathrm{DI}=\frac{\mathrm{A}-\mathrm{M}}{\mathrm{A}+\mathrm{O}+\mathrm{I}+\mathrm{M}}, \operatorname{cSI} \in[-1,1]$

where:

$A$ - attractive qualities

$O$-expected qualities

$M$-basic qualities

$I$-indifferent qualities

The higher approximation of SI result to value 1 for a particular requirement, the higher is the influence of this requirement on the client's satisfaction (in the case it is fulfilled). The higher approximation of DI result to -1 , the greater is the influence of the unfulfilled requirement on student dissatisfaction. The higher approximation of SI and DI results to zero, the smaller is the influence of the requirement on student satisfaction or dissatisfaction.

\section{Sample description and result analysis}

In November 2016, a survey was conducted whose aim was to specify the qualities which should characterize an educational service from the recipient's student's - point of view. The sample selection was non-random in its nature. The survey included $218(76 \%)$ of students of the first year of the part-time, second-cycle studies at WSB University of Wrocław, Faculty of Economics in Opole - lecture participants within the framework of one of the mandatory subjects. Students were asked to evaluate the organization in terms of the study, seminar timetable, 
facilitations, and infrastructure, as well as to characterize the lecturer (according to the recommendations of the Kano method).

Table 3 presents the prioritization of the client's/student's requirements in relation to the lecturer according to the recommendations of the Kano method.

Table 3. The lecturer characteristics $(\mathbf{n}=\mathbf{2 1 8})$ - requirement prioritization according to the Kano method

\begin{tabular}{|l|c|c|c|c|c|c|c|}
\hline & \multirow{2}{*}{$\begin{array}{c}\text { Requireme } \\
\text { nt } \\
\text { category }\end{array}$} & \multicolumn{5}{|c|}{ Number of indications } \\
\cline { 5 - 8 } & $\mathrm{M}$ & $\mathrm{M}$ & $\mathrm{O}$ & $\mathrm{R}$ & $\mathrm{Q}$ & $\mathrm{I}$ \\
\hline $\begin{array}{l}\text { the lecturer shows good theoretical } \\
\text { knowledge }\end{array}$ & $\mathrm{M}$ & 116 & 73 & 0 & 0 & 22 \\
\hline $\begin{array}{l}\text { the lecturer clearly defines the student's } \\
\text { obligations }\end{array}$ & $\mathrm{M}$ & 13 & 97 & 76 & 0 & 0 & 32 \\
\hline $\begin{array}{l}\text { the lecturer answers questions } \\
\text { professionally }\end{array}$ & $\mathrm{M}$ & 16 & 97 & 82 & 0 & 0 & 23 \\
\hline the lecturer is communicative & $\mathrm{M}$ & 18 & 91 & 86 & 0 & 0 & 23 \\
\hline $\begin{array}{l}\text { the lecturer provides good practical } \\
\text { examples }\end{array}$ & $\mathrm{M}$ & 23 & 88 & 84 & 0 & 0 & 23 \\
\hline $\begin{array}{l}\text { the lecturer has a friendly attitude towards } \\
\text { students }\end{array}$ & $\mathrm{O}$ & 14 & 93 & 98 & 0 & 0 & 13 \\
\hline $\begin{array}{l}\text { the lecturer covers the material to prepare } \\
\text { students for coping with everyday } \\
\text { problems }\end{array}$ & $\mathrm{O}$ & 35 & 70 & 84 & 0 & 0 & 29 \\
\hline $\begin{array}{l}\text { the lecturer facilitates discussion during } \\
\text { classes }\end{array}$ & $\mathrm{O}$ & 40 & 51 & 71 & 2 & 3 & 51 \\
\hline $\begin{array}{l}\text { the lecturer is available to students after } \\
\text { classes (e.g. on duty, per e-mail) }\end{array}$ & $\mathrm{O}$ & 39 & 54 & 102 & 1 & 0 & 22 \\
\hline
\end{tabular}

Source: the authors' own calculations based on the survey results

It can be gleaned from the table above that among the requirements relating to the lecturer's qualities which students perceive as necessary to satisfy the basic needs ("M" category) the following were included: a clear definition of students' obligations, good theoretical knowledge, the ability to provide good practical examples, the ability to answer questions "professionally" and communication skills. There are four requirements which students viewed as functional and desirable ("O" category). These were the following: the lecturer covers the material to prepare students for coping with everyday problems, a friendly approach to students, 
APPLICATION OF KANO QUESTIONNAIRE TO ASSESS THE LEVEL OF TEACHING ...

facilitating discussion during classes, as well as the lecturer's availability after classes.

Next, those elements were indicated which proved to be the most important in terms of exerting influence on students' satisfaction and dissatisfaction (see Table 4, Chart 1)

Table 4. The lecturer characteristics $(n=218)$ - satisfaction evaluation

\begin{tabular}{|l|c|c|c|}
\hline & $\begin{array}{c}\text { Satisfaction } \\
\text { extent } \\
\text { (SI) }\end{array}$ & $\begin{array}{c}\text { Dissatisfaction } \\
\text { extent (DI) }\end{array}$ & $\begin{array}{c}\text { Total } \\
\text { satisfaction } \\
\text { (CSI) }\end{array}$ \\
\hline $\begin{array}{l}\text { the lecturer shows good theoretical } \\
\text { knowledge }\end{array}$ & 0.37 & -0.53 & -0.16 \\
\hline $\begin{array}{l}\text { the lecturer clearly defines the student's } \\
\text { obligations }\end{array}$ & 0.41 & -0.44 & -0.03 \\
\hline $\begin{array}{l}\text { the lecturer answers questions } \\
\text { professionally }\end{array}$ & 0.45 & -0.44 & 0.01 \\
\hline the lecturer is communicative & 0.48 & -0.42 & 0.06 \\
\hline $\begin{array}{l}\text { the lecturer provides good practical } \\
\text { examples }\end{array}$ & 0.49 & -0.40 & 0.09 \\
\hline $\begin{array}{l}\text { the lecturer has a friendly attitude } \\
\text { towards students }\end{array}$ & 0.51 & -0.43 & 0.08 \\
\hline $\begin{array}{l}\text { the lecturer covers the material to } \\
\text { prepare students for coping with } \\
\text { everyday problems }\end{array}$ & 0.55 & -0.32 & 0.23 \\
\hline $\begin{array}{l}\text { the lecturer facilitates discussion during } \\
\text { classes }\end{array}$ & 0.52 & -0.25 & 0.27 \\
\hline $\begin{array}{l}\text { the lecturer is available to students after } \\
\text { classes (e.g. on duty, per e-mail) }\end{array}$ & 0.65 & -0.25 & 0.40 \\
\hline
\end{tabular}

Source: The authors' own calculations based on the survey results

The above list shows that the requirements exerting the most substantial influence on the student's satisfaction (the value of satisfaction ratio near 1) include the following: the lecturer's availability after classes $(+65)$, the lecturer covers the material to prepare students for coping with everyday problems $(+55)$, and the lecturer facilitates discussion during classes $(+0.52)$. Their presence increases the level of the client's satisfaction more than any other requirements. With respect to the client's dissatisfaction, we can conclude that: the highest level of dissatisfaction among students was caused by the lecturer's lacking theoretical knowledge $(-0.53)$. 
The two following items were ranked as the second ex aequo: the lecturer clearly defines the student's obligations (-0.44) and the lecturer provides professional answers (-0.44). These requirements yield a high level of dissatisfaction when they are not met, since the students take their presence for granted.

A graphic depiction of the evaluation of satisfaction from the requirement met and the evaluation of dissatisfaction from failing to fulfill the requirement is presented in Chart 1.

Chart 1. Lecturer characteristics $(n=218)$ - evaluation of satisfaction from the requirement fulfillment, evaluation of dissatisfaction from failing to fulfill the requirement

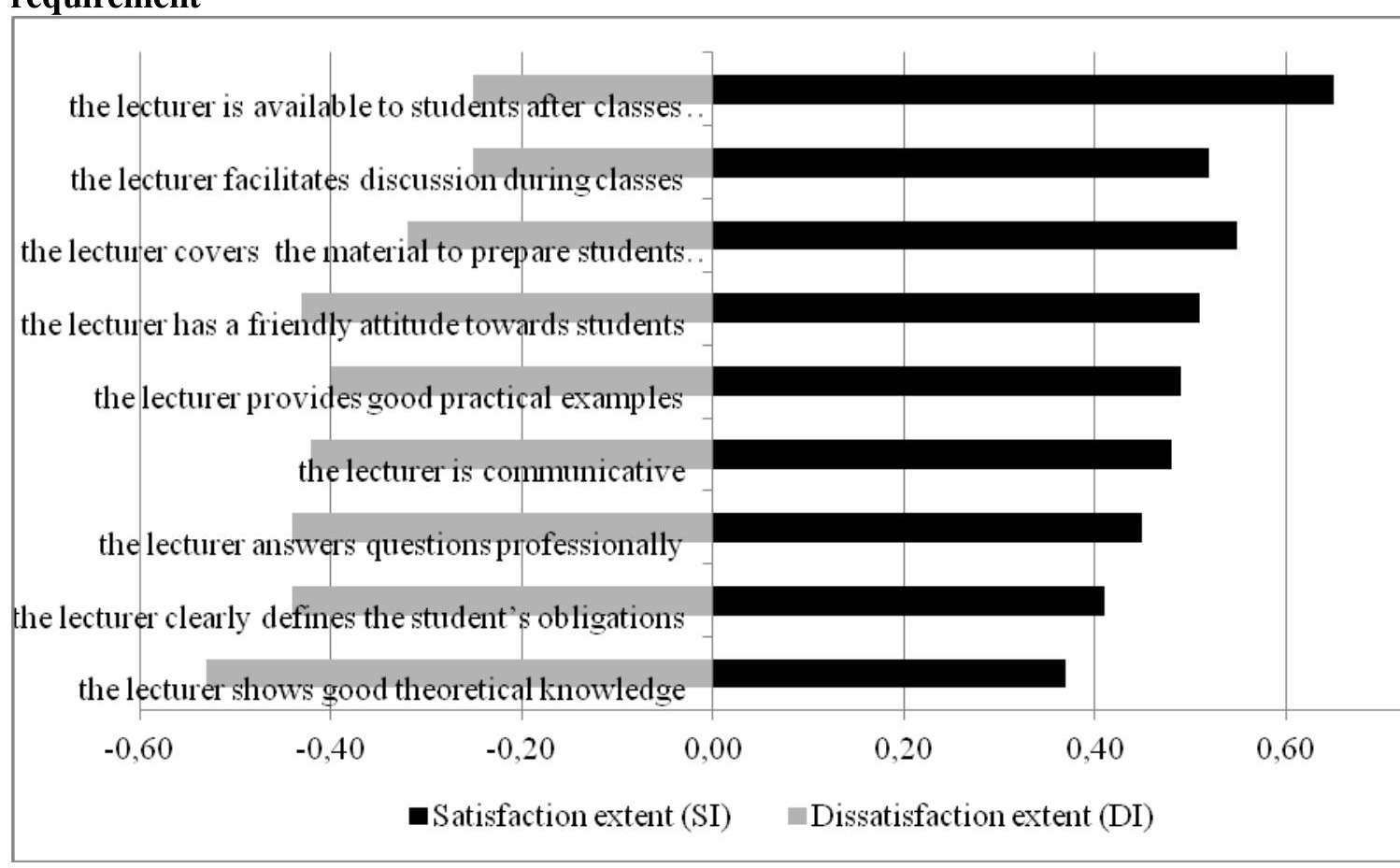

Source: The authors' own calculations based on the survey results

During the next stage it was indicated which elements are the most important from the student's point of view in relation to the overall satisfaction (see Table 4, Chart 2). 


\section{Chart 2. Lecturer characteristics $(n=218)$ - overall satisfaction evaluation}

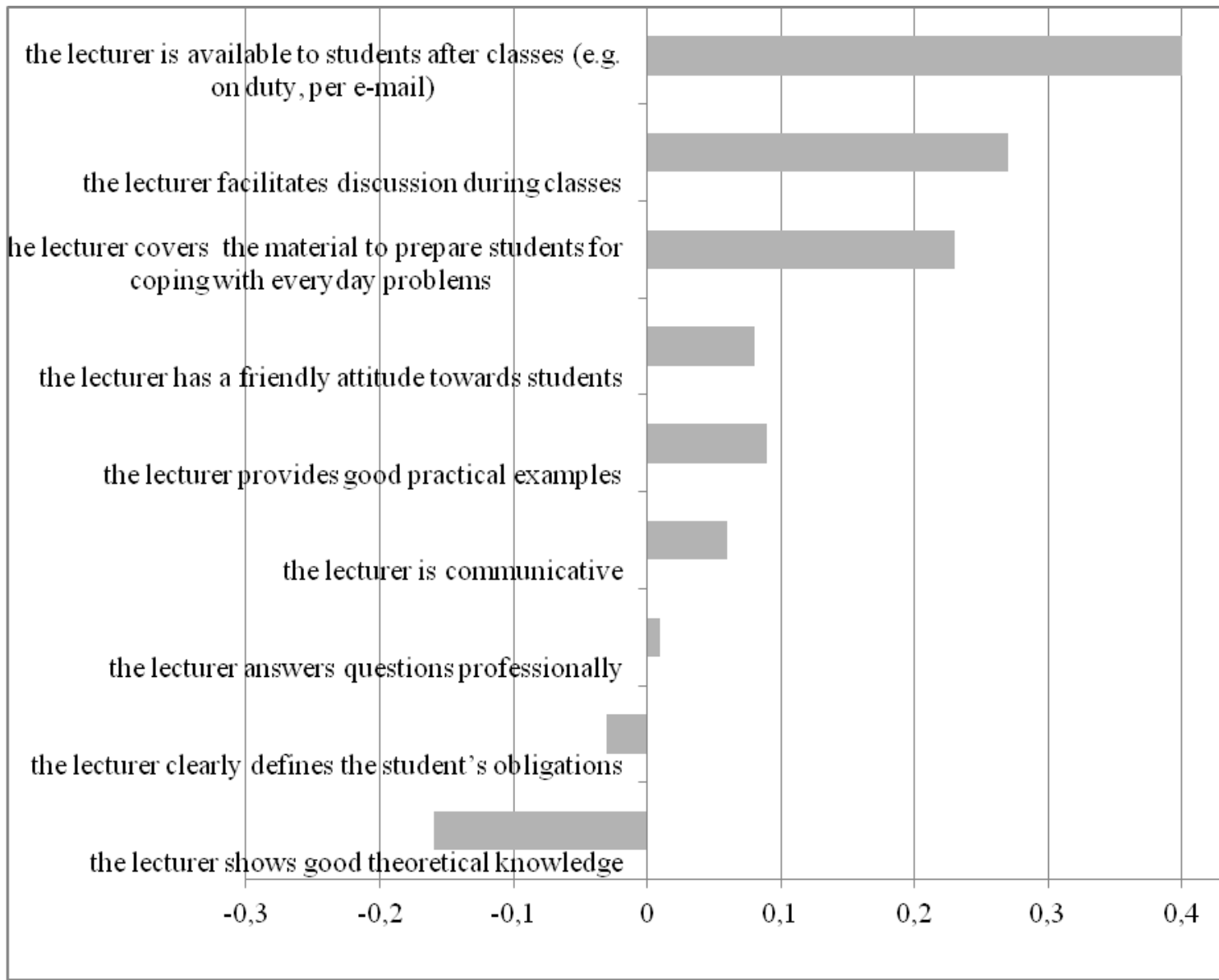

Source: The authors' own calculations based on the survey results

The requirements which exert the highest influence on the student's total satisfaction include the following: the lecturer's availability after classes $(+0,39)$, facilitating discussion during classes $(+0.27)$ and covering the material to prepare students for coping with everyday problems $(+0.23)$. Seven qualities were present in the group of requirements whose fulfillment resulted in a satisfaction that was higher than dissatisfaction from failing to meet the requirements.

In the group of requirements which when not met cause dissatisfaction higher than the satisfaction from fulfilling the requirements two qualities were present: 


\section{Anna SZELIGA-DUCHNOWSKA, Mirosława SZEWCZYK}

lecturer shows good theoretical knowledge and lecturer clearly defines the student's obligations.

\section{Concluding remarks}

The determination of the requirement categories in the light of the Kano method can be used in defining the way forward by University authorities. In summing up the results of the survey conducted by the authors the recommendation for a given university within the category "teaching staff quality" is to provide teaching staff who shows good theoretical knowledge and ensures that students' obligations are clearly defined. These two requirements are necessary for the basic needs to be satisfied ("M" category), while failure to fulfill them results in higher dissatisfaction than the satisfaction from the requirement fulfillment.

The above analysis of the subject-specific literature and the survey has found that the Kano model allows for finding out the answer to the question how students assess a lecturer and indicates the most important characteristics to be improved in terms of teaching staff quality.

The Kano questionnaire can serve as an excellent (insightful, precise and specific) tool in the evaluation of teaching staff by students/clients of a higher education institution, being an alternative to the traditional survey questionnaires. The findings obtained through the Kano questionnaire are valuable feedback both for lecturers and university authorities in terms of the information which qualities of the teaching staff should be developed in particular and which are of no significance to students. 


\section{References}

Arefi M., Heidari M., Shams Morkani G., Zandi K. (2012), Application of Kano Model in higher education quality improvement: study master's degree program of educational psychology in State Universities of Tehran, „World Applied Sciences Journal”2012, vol. 17 no. 3, pp. 347-353.

Bauk S., Šćepanović S., Kopp M. (2014), Estimating students' satisfaction with web based learning system in blended learning environment, "Education Research International", http://dx.doi.org/10.1155/2014/731720

Berger C., Blauth R., Boger D., Bolster C., Burchill G., DuMouchel W., Pouliot F., Richter R., Rubinoff A., Shen D., Timko M., Walden D. (1993), Kano's methods for understanding customer-defined quality, "CQMJ", vol. 4, pp. 3-36.

Bilgili B., Erciş A., Ünal S. (2011), Kano model application in new product development and customer satisfaction (adaptation of traditional art of tile making to jewelries), "Procedia - Social and Behavioral Sciences", vol. 24, pp.829-846, http://dx.doi.org/10.1016/j.sbspro.2011.09.058.

Detyna B. (2011), Zarządzanie jakością w logistyce. Metody i narzędzia wspomagające. Przykłady, zadania, Wydawnictwo Państwowej Wyższej Szkoły Zawodowej w Wałbrzychu, Wałbrzych.

Drule A. M., Popa I. E., Nistor R., Chis A. (2014) Quality of the teaching process and its factors of influence from the perspective of future business specialists, "The Amfiteatru Economic Journal", vol. 16 no. 37 , pp.827-840.

Dominici G., Palumbo F. (2013), How to build an e-learning product: factors for student/customer satisfaction, "Business Horizons", vol. 56, pp. 87-96.

Fazlagić J. (2012), Kapitał intelektualny szkoły wyższej z perspektywy studentów, „E-mentor”, vol. 3 no. 45 , pp. $77-85$.

Grudowski P., Dembowski J. (2012), Metoda Kano w analizie satysfakcji klienta, „Pieniądze i Więź”, vol. $15 / 1$ no. 54 , pp. $77-87$.

Hamrol A. (2007), Zarządzanie jakością z przykładami, Wydawnictwo Naukowe PWN, Warszawa.

Kano N., Seraku N., Takahashi F., Ichi Tsuji S. (1984), Attractive quality and must-be quality. "Journal of the Japanese Society for Quality Control” (in Japanese), vol. 14 no. 2, pp. 147-156.

Malinowska E. (2010), Ocena stopnia satysfakcji klienta wewnętrznego systemu bezpieczeństwa żywności z wykorzystaniem metody Kano, „Zarządzanie Jakością, Doskonalenie Organizacji”, vol. 2, pp. 467-477.

Malinowska E., Wiśniewska M., Grudowski P. (2014), Pomiar jakości usług edukacyjnych z wykorzystaniem metody Kano, „Prace Naukowe Uniwersytetu Ekonomicznego we Wrocławiu”, vol. 354, pp. 235-247.

Ratajczak S. (2012), Jakość kształcenia w szkołach wyższych w perspektywie interesariuszy, Wyższa Szkoła Biznesu w Dąbrowie Górniczej, Dąbrowa Górnicza. 


\section{Anna SZELIGA-DUCHNOWSKA, Mirosława SZEWCZYK}

Sauerwein E., Franz B., Kurt M., Hans H. (1996), The Kano model: how to delight your customers, IX International Working Seminar on Production Economics, Innsbruck/Igls/Austria, vol. 1, pp. 313-327.

Sia M. K., Muthusamy K. (2012), Classifying quality attributes using service gaps and Kano's method, „International Conference on Economics, Business Innovation”, vol. 38, pp. 230-235.

Taifa, I. W., Desai, D.A. (2016), Student-defined quality by Kano model: a case study of engineering students in India. "International Journal for Quality Research", vol. 1 no. 1), pp. 569-582.

Wolniak R., Skotnicka B. (2008), Metody i narzędzia zarządzania jakością. Teoria i praktyka, Wyd. Politechniki Śląskiej, Gliwice.

Xiao J., Wilkins S. (2015), The effects of lecturer commitment on student perceptions of teaching quality and student satisfaction in Chinese higher education, "Journal of Higher Education Policy and Management”, vol. 37 no. 1, pp. 98-110.

Wolniak R., Skotnicka B. (2008), Metody i narzędzia zarządzania jakością. Teoria i praktyka, Wyd. Politechniki Śląskiej, Gliwice.

Xiao J., Wilkins S. (2015), The effects of lecturer commitment on student perceptions of teaching quality and student satisfaction in Chinese higher education, "Journal of Higher Education Policy and Management”, 37(1), pp. 98-110. 